Journal of Attention Disorders Vol. 3(1):30-48 (1999)

ISSN: 1087-0547

doi:10.1177/108705479900300103

This is a peer reviewed pre-print version of the following article: Treatment alternatives for Attention-Deficit/ Hyperactivity Disorder (ADHD), which has been published in final form at:

http://www.sagepub.com/home.nav

http://jad.sagepub.com/

http://jad.sagepub.com/content/3/1/30.full.pdf+html

(C) Multi-Health Systems Inc., 1999

\title{
Treatment alternatives for Attention-Deficit/ Hyperactivity Disorder (ADHD)
}

\section{L.E. Arnold}

Objective

To review alternate treatments (Tx) of Attention-Deficit/Hyperactivity Disorder (ADHD)—those other than psychoactive medication and behavioral/psychosocial Tx-for the November, 1998 National Institute of Health (NIH) Consensus Development Conference on ADHD.

Method:

The literature was searched on Medline and Psychlnfo 1963-1998 and investigators known to be interested in alternate Tx were contacted for unpublished data.

Results:

Twenty-three alternate Tx were identified, ranging in scientific documentation from discrediting controlled studies through mere hypotheses to positive controlled double-blind clinical trials. Many of them are applicable only to a restricted etiological subgroup. The oligoantigenic or few-foods diet has convincing double-blind evidence of efficacy in multiple trials for a properly selected subgroup. Enzyme-potentiated desensitization to foods, relaxation/EMG biofeedback, and deleading also have controlled evidence of efficacy. Glyconutritional supplementation, iron supplementation, magnesium supplementation, Chinese herbals, EEG biofeedback, meditation, mirror feedback, channel-specific perceptual training, and vestibular stimulation all have promising prospective pilot data. Single-vitamin megadosage has some intriguing pilot trial data. Zinc supplementation is hypothetically supported by systematic case-control data but has no systematic clinical trial. Laser acupuncture has promising unpublished pilot data. Essential fatty acid supplementation has promising systematic case-control data but clinical trials are equivocal.

Recommended-Daily-Allowance vitamin supplementation, nonChinese herbals, homeopathic remedies, and antifungal therapy have no systematic data in ADHD. Megadose multivitamin combinations are probably ineffective for most patients and possibly dangerous. Simple sugar restriction and hypnosis seem ineffective. Amino acid supplementation, though mildly effective in the short term, is not effective beyond a few weeks. Thyroid Tx is effective in the presence of documented thyroid abnormality, but not otherwise.

Conclusion

Some alternate Tx of ADHD are effective or probably effective, but mainly for restricted etiologic subgroups. In some cases they are the Tx of choice, and initial evaluation should consider the relevant etiologies. A few have failed to prove effective in controlled trials. Most need research to determine whether they are effective and/or to define the applicable subgroup. Some of them, though not safer than standard Tx, may be preferable for an etiologic subgroup.

Attention-Deficit/Hyperactivity Disorder (ADHD) has attracted many kinds of proposed treatments. The National Institute of Health (NIH) Consensus Development Conference on Diagnosis and Treatment of ADHD, held November 16-18, 1998 at Bethesda, MD, required a comprehensive review of possible treatments. Alternate treatments (Tx), or treatment alternatives, were defined for this purpose as any treatment other than prescription psychoactive drugs or standard behavioral/psychosocial treatments, both of which have already been extensively and 
well reviewed in the extant literature, with undoubted efficacy. In contrast to those two more general, established treatments, many alternate treatments are etiologically targeted (see Table 1) and consequently 


\begin{tabular}{|c|c|c|c|c|c|}
\hline Treatment & Etiology or mechanism & Type of data & ESorp & $\begin{array}{l}\text { Rating* }(0-6) ; \\
\text { recommendation }\end{array}$ & Risks \\
\hline $\begin{array}{l}\text { Few foods diet } \\
\text { (Oligoantigenic) }\end{array}$ & $\begin{array}{l}\text { Food or additive } \\
\text { sensitivity }\end{array}$ & $\begin{array}{l}\text { Controlled trial; } \\
\text { placebo challenges }\end{array}$ & $\begin{array}{l}\text { ES 0.5-1.5 } \\
\text { p .05-.001 }\end{array}$ & $\begin{array}{l}\text { 5; define subgroup } \\
\text { (profile; \% ADHD) }\end{array}$ & Nuisance, expense, nutrition \\
\hline $\begin{array}{l}\text { Enzyme-potentiate } \\
\text { d }\end{array}$ & Food or additive & Controlled comparison & p.001 & 4; replication; define & Injection \\
\hline desensitization & sensitivity & to placebo injections & & subgroup & \\
\hline $\begin{array}{l}\text { Elimination of } \\
\text { sugar }\end{array}$ & Sugar malaise & Placebo-controlled & $\mathrm{p}^{>} .1$ & 0 ; take FH of DM & Delay std Tx \\
\hline alone & & challenges & & & \\
\hline $\begin{array}{l}\text { Amino acid } \\
\text { supplementation }\end{array}$ & $\begin{array}{l}\text { Precursors of } \\
\text { catecholamines }\end{array}$ & $\begin{array}{l}\text { Placebo-controlled } \\
\text { comparisons }\end{array}$ & $\begin{array}{l}E S \text { up to } 0.6 \\
\text { p.01 }\end{array}$ & $\begin{array}{l}0 \text {; despite short-lived } \\
\text { effect of little utility }\end{array}$ & Eosinophilia, neurotoxicity \\
\hline $\begin{array}{l}\text { Essential fatty acid } \\
\text { supplementation }\end{array}$ & $\begin{array}{l}\text { Prostaglandins, } \\
\text { Neural membrane }\end{array}$ & $\begin{array}{l}\text { Serum level cf. cntrl } \\
\text { plac.-contr. trials }\end{array}$ & $\begin{array}{l}E S .05 \\
.1>\mathrm{p}>.05\end{array}$ & $\begin{array}{l}3 \text {; trials of } n-3< \\
\text { in selected subjects }\end{array}$ & Upsetting balance \\
\hline $\begin{array}{l}\text { Glyconutritional } \\
\text { supplementation }\end{array}$ & Need for glycoconjugates & $\begin{array}{l}\text { Open trials, SNAP-IV, } \\
\text { blind teachers }\end{array}$ & p .05-.002 & 3; placebo trials & Upsetting balance \\
\hline Vitamins & $\begin{array}{l}\text { Deficiency or idiopathic } \\
\text { need for higher dose }\end{array}$ & $\begin{array}{l}\text { Placebo-controlled } \\
\text { trials megavitamin } \\
\text { combo, not RDA }\end{array}$ & $\begin{array}{l}\text { Megadose } \\
\text { combo no } \\
\text { benefit }\end{array}$ & $\begin{array}{l}0 \text { for mega-combo; } \\
1 \text { for RDA, specific } \\
\text { megavit; pilot trials }\end{array}$ & $\begin{array}{l}\text { Hepatotoxicity, neuropathy } \\
\text { in megadose }\end{array}$ \\
\hline $\begin{array}{l}\text { Iron supple- } \\
\text { mentation }\end{array}$ & $\begin{array}{l}\text { Co-factor in making } \\
\text { catecholamines }\end{array}$ & $\begin{array}{l}\text { Open trial } \\
\text { supplementation }\end{array}$ & $\begin{array}{l}\text { ES } 1.0 \\
\mathrm{p}<.05\end{array}$ & $3^{* *}$; controlled trials & $\begin{array}{l}\text { Hemochromatosis from } \\
\text { excess }\end{array}$ \\
\hline $\begin{array}{l}\text { Zinc supple- } \\
\text { mentation }\end{array}$ & $\begin{array}{l}\text { Co-factor for } \\
\text { many enzymes }\end{array}$ & $\begin{array}{l}\text { Comparison Zn level of } \\
\text { ADHDtocontrl }\end{array}$ & $\begin{array}{l}\text { ES } 2.4 \\
\mathrm{p}<.001\end{array}$ & $2^{* *}$; controlled trials & WBC aplasia from excess \\
\hline $\begin{array}{l}\text { Magnesium } \\
\text { supplementation }\end{array}$ & Deficiency cf. to controls & $\begin{array}{l}\text { Open trial with control } \\
\text { group }\end{array}$ & $\begin{array}{l}\text { ES 1.2-1.4 } \\
\mathrm{p}<.05\end{array}$ & $3^{* *}$; placebo trials & Aggression from excess \\
\hline Chinese herbals & Clinical exper. & $\begin{array}{l}\text { Open trials, one with } \\
\text { MPH control }\end{array}$ & $\begin{array}{l}\mathrm{p}<.05 ; \text { no } \\
\text { diff. } \mathrm{MPH}\end{array}$ & 3; placebo trials & Delay of other Tx \\
\hline
\end{tabular}




\begin{tabular}{|c|c|c|c|c|c|}
\hline Other herbals & Clinical exper. & No data & N.A. & 1; pilot trials & Delay otherTx \\
\hline Homeopathic prep & Clinical exper. & No data & N.A. & 1; pilot trials & Delay otherTx \\
\hline Laser acupuncture & Stimulate foci for calming & Open trial & ES 1.0 & 2 ; controlled trial & Delay burn,other Tx \\
\hline EEG biofeedback & Suppress theta, increase beta & $\begin{array}{l}\text { Open \& randomized } \\
\text { wait list Ctrl trials }\end{array}$ & $\mathrm{p}<0.05$ & 3; sham-controlled trial & Expense, time \\
\hline $\begin{array}{l}\text { EMG biofeedback, } \\
\text { relaxat'n, hypnosis }\end{array}$ & Lower arousal, muscle tone & $\begin{array}{l}\text { Randomized trials with } \\
\text { controls }\end{array}$ & $\begin{array}{l}\text { ES } 1.0-1.3 \\
\mathrm{p}<0.01\end{array}$ & $\begin{array}{l}0 \text { for hypnosis; } 4 \text { for } \\
\text { EMG/relax'n; cf. med }\end{array}$ & Delay other Tx \\
\hline Meditation & $\begin{array}{l}\text { Autonomic effect, } \\
\text { focused attention }\end{array}$ & $\begin{array}{l}\text { Cf. relaxation, wait list } \\
\text { Ctrl, med }\end{array}$ & $\mathrm{p}<.05$ & $\begin{array}{l}\text { 3; rigorous replica- } \\
\text { tion, sham ctrl }\end{array}$ & Delay other Tx \\
\hline Mirror feedback & $\begin{array}{l}\text { Improve deficiency of self- } \\
\text { focus }\end{array}$ & $\begin{array}{l}\text { Randomized x-over } \\
\text { w. \& w/o, cf. controls }\end{array}$ & $\begin{array}{l}\text { ES } 0.5 \\
\mathrm{p}<.05\end{array}$ & $\begin{array}{l}\text { 3; replication, instruc- } \\
\text { tion to look }\end{array}$ & $\begin{array}{l}\text { May impair non-ADHD } \\
\text { children }\end{array}$ \\
\hline $\begin{array}{l}\text { Channel-specific } \\
\text { perceptual training }\end{array}$ & Basic readiness skills, focus & $\begin{array}{l}\text { Randomized prev. trial } \\
\text { with } 2 \text { control grps }\end{array}$ & $\begin{array}{l}E S 0.9 \\
\mathrm{p}<0.01\end{array}$ & 3; controlled Tx trials & $\begin{array}{l}\text { Delay other Tx } \\
\text { (continued overleaf) }\end{array}$ \\
\hline $\begin{array}{l}\text { Vestibular } \\
\text { stimulation }\end{array}$ & $\begin{array}{l}\text { Modulate behav., att'n, } \\
\text { perception }\end{array}$ & $\begin{array}{l}\text { Open \& single-blind } \\
\text { trials }\end{array}$ & $\begin{array}{l}\text { ES } 0.4-1.2 \mathrm{p} \\
\mathrm{ns}-0.001\end{array}$ & $\begin{array}{l}\text { 3; randomized } \\
\text { sham-controlled trials }\end{array}$ & Nausea, accident \\
\hline Antifungal Tx & $\begin{array}{l}\text { Gl yeast toxin; breach of } \\
\text { mucosa }\end{array}$ & $\begin{array}{l}\text { No data in ADHD; } \\
\text { other placebo trials }\end{array}$ & $\begin{array}{l}\text { ES } 1.1-3 \mathrm{p}< \\
0.003\end{array}$ & 1 ; trials in $\mathrm{ADHD}$ & Medical risk \\
\hline Thyroid Tx & Thyroid Fx affects AD Sx & $\begin{array}{l}\text { Placebo trial: } 5 / 8 \\
\text { GRTH, } 1 / 9 \text { other }\end{array}$ & $\begin{array}{l}\text { ns if thyr. not } \\
\text { abnormal }\end{array}$ & $\begin{array}{l}0 \text { if thyroid normal; } 6 \text { if } \\
\text { thyroid abnormal }\end{array}$ & Thyroid toxicity \\
\hline Deleading & Lead toxicity causes AD Sx & $\begin{array}{l}\text { Placebo-ctrl trial of } \\
\text { chelation (=MPH) }\end{array}$ & $\begin{array}{l}E S 0.7-1.6 \mathrm{p} \\
0.5-.001\end{array}$ & $\begin{array}{l}4 \text { if blood } \mathrm{Pb}>20 ; 2 \text { if } \\
\mathrm{Pb}<20 \text {; Ctrl trial }\end{array}$ & Toxicity of chelator \\
\hline
\end{tabular}


Psy = Psychological; Ss = subjects; Sx = symptoms; $\mathrm{x}$-over $=$ crossover

Table 1. Scientific status of alternate treatments (Tx) for ADHD 
applicable to a smaller subpopulation of patients with ADHD. Therefore, scientific evaluation and clinical use of such treatments requires more etiological depth of diagnosis than the phenomenological criteria of DSM-IV.

The treatments summarized here do not exhaust all the alternatives tried or advocated in various quarters, but are those for which either peer-reviewed literature or unpublished data could be found through two strategies: 1) search on numerous keywords in Medline and Psychlnfo from the beginning to 1998; 2) informal contacts with dozens of people-both professional and nonprofessional-knowledgeable about or active in various alternate treatments. For lack of space, referencing for some of the more popular treatments is more illustrative than exhaustive.

\section{Elimination Diets (Oligoantigenic or Few-Food Diet)}

At the time of the 1982 NIH Consensus Development Conference on Defined Diets and Hyperactivity (NIH, 1982) most elimination diets (defined diets) were popularly known as Feingold diets. The Feingold (1975) hypothesis had stated that many children are sensitive to dietary salicylates and artificially added colors, flavors, and preservatives, and that learning and behavior problems, including ADHD, could be ameliorated by eliminating the offending substances from the diet. Despite a few positive studies (e.g., Swanson \& Kinsbourne, 1981; Williams \& Cram, 1978), most controlled studies were interpreted by the investigators and reviewers/meta-analyzers as nonsupportive of the hypothesis (Conners, 1980; Mattes, 1983; Kavale \& Forness, 1983). These interpretations were challenged by Feingold (1981) and his advocates (Rimland, 1983; Rippere, 1983) on several grounds, including these: 1) narrow restriction of tests to food dyes-Feingold (1981) actually anticipated within different children hypersensitivity to thousands of different substances, and had merely suggested food colorings as a good place to begin controlled studies because of their ubiquity and ease of control; he had not meant to equate his diet with elimination of dyes; 2) too low dosage levels of dyes used in challenges; 3) arbitrary ignoring of positive findings in certain subgroups; 4) ignoring of animal studies. In such equivocal circumstances the 1982 consensus panel called for more controlled research. 


\begin{tabular}{|c|c|c|c|c|}
\hline Reference & Subjects & Design & Results & ES,p \\
\hline Eggeretal., 1985 & $\begin{array}{l}\text { Special diet clinic; HK, } \\
\text { Conners > } 14\end{array}$ & $\begin{array}{l}76 \text { Ss open trial few foods; } 28 \text { Ss } \\
\text { placebo } x \text {-over challenge }\end{array}$ & $\begin{array}{l}\text { 62/76 improved in trial; } \\
\text { 23/28 better on placebo, } \\
\text { worse on challenge }\end{array}$ & p.001 \\
\hline Kaplan et al., 1989 & $\begin{array}{l}\text { Ads, DSM-III, Conners } 1 \text { sd, } \\
\text { physical Sx }\end{array}$ & $\begin{array}{l}24 \text { preschoolers placebo diet } \\
\text { x-over ( } 3+4 \text { wk) with all food } \\
\text { provided; multiple elimination }\end{array}$ & $\begin{array}{l}\text { Over half had reliable } \\
\text { behavior improvement, no } \\
\text { placebo effect }\end{array}$ & ES 0.5 p.01 \\
\hline $\begin{array}{l}\text { Pollock \& Warner, } \\
1990\end{array}$ & $\begin{array}{l}\text { Ped. allergy clinic, survey; } \\
\text { selected by parent-observ. } \\
\text { behv. }\end{array}$ & $\begin{array}{l}39 \text { Ss placebo-controlled dye } \\
\text { challenge while on elimination } \\
\text { diet; only } 19 \text { completed }\end{array}$ & $\begin{array}{l}\text { Food colors small adverse } \\
\text { effect on Conners rating, not } \\
\text { globally detected by parent }\end{array}$ & ES small $\mathrm{p}<.01$ \\
\hline Egger et al., 1992 & $\begin{array}{l}\text { Special diet clinic; HK } \\
\text { criteria, Conners Index }>15\end{array}$ & $\begin{array}{l}185 \text { Ss } 4 \text {-wk open few foods; } 40 \\
\text { Ss parallel random assignm. to } \\
\text { plac. or enzyme-potentiated } \\
\text { desensitization (EPD) }\end{array}$ & $\begin{array}{l}\text { 116/185 responded openly } \\
\text { with reintroduction; } 16 / 20 \\
\text { with EPD, only } 4 / 20 \text { with } \\
\text { placebo became tolerant }\end{array}$ & p.001 \\
\hline Carter et al., 1993 & $\begin{array}{l}\text { Special diet clinic; HK } \\
\text { criteria, Conners Index > } 15\end{array}$ & $\begin{array}{l}78 \text { Ss open trial few foods; } \\
23 \text { placebo x-over challenge } \\
\text { with } \\
\text { provoking foods; } 19 \text { completed }\end{array}$ & $\begin{array}{l}\text { 59/78 improved openly; } \\
\text { 14/19 placebo better } \\
\text { behavior and Psychological } \\
\text { test }\end{array}$ & p .05-.01 ES 0.6 \\
\hline Rowe \& Rowe, 1994 & $\begin{array}{l}\text { Hyperactivity referrals } \\
\text { hospital ped. clinic }\end{array}$ & $\begin{array}{l}200 \text { Ss } 6 \text {-wk open dye-free diet; } \\
34 \text { Ss ( } 23 \text { reactors; } 11 \text { uncertain) } \\
\& 20 \text { controls 3-wk daily repeat } \\
\text { plac. cf. to } 6 \text { doses tartrazine }\end{array}$ & $\begin{array}{l}\text { 150/200 improved, relapsed } \\
\text { on open challenge; } 19 / 23 \text {, } \\
\text { 3/11, and 2/20 clear reactors; } \\
\text { irritable, restless, sleep } \\
\text { disturb. }\end{array}$ & ES 0.8 p.05 \\
\hline $\begin{array}{l}\text { Boris \& Mandel, } \\
1994\end{array}$ & $\begin{array}{l}\text { DSM-III-R criteria for } \\
\text { ADHD }\end{array}$ & $\begin{array}{l}26 \text { Ss open multiple elimination; } \\
19 \text { responders } \\
\text { placebo-controlled DB } \\
\text { challenge; } 16 \text { completed }\end{array}$ & $\begin{array}{l}\text { 19/26 openly responded; } \\
\text { placebo days significantly bet- } \\
\text { ter than challenge days }\end{array}$ & p.001 p.003 ES 1.5 \\
\hline Schmidt et al., 1997 & $\begin{array}{l}\text { Hyperactive, disruptive } \\
\text { inpatients }\end{array}$ & $\begin{array}{l}49 \text { Ss in DB placebo x-over of } \\
\text { oligoantigenic \& control diet; } 36 \\
\text { also compared to MPH }\end{array}$ & $\begin{array}{l}\text { 12/49 significant behavioral } \\
\text { improvement cf. control diet; } \\
\text { 16/36 resp. MPH }\end{array}$ & \\
\hline
\end{tabular}

DB = double-blind; ; MPH = methylphenidate; $\mathrm{Pl}$, plac = placebo

Table 2. Controlled studies of few-food (oligoantigenic) diets. (ES = effect size, Cohen's d) 
Since then, at least 8 controlled studies (Table 2; Breakey, 1997) have demonstrated either significant improvement compared to a placebo condition (disguised full diet) (Kaplan, McNicol, Conte, \& Moghadam, 1989a; Schmidt et al., 1997) or deterioration on a placebo-controlled challenge of offending substances after an open diet trial and open challenge to identify the substance (Egger, Carter, Graham, Gumley, \& Soothill, 1985; Egger, Stolla, \& McEwen, 1992; Pollock \& Warner, 1990; Carter et al, 1993; Rowe \& Rowe, 1994; Boris \& Mandel, 1994). One report (Rowe, 1988) suggested that those who reliably respond to dye challenges constitute a small proportion and are more likely the hyperactive-impulsive subtype. The finding of scientifically acceptable documentation of efficacy since 1982 appears associated with broadening the range of suspected food items, selecting subjects more carefully (e.g., for allergic diathesis), and allowing for the timing peculiarities of food sensitivities. A typical oligoantigenic or few-foods diet might exclude everything except the following: lamb, chicken, potatoes, rice, banana, apple, brassica (cabbage, cauliflower, broccoli, brussels sprouts), cucumber, celery, carrots, parsnip, salt, pepper, calcium, and vitamins. A related Tx possibility arises from the documentation of successful desensitization to the offending food by enzyme-potentiated desensitization (Esser et al., 1992). The main scientific task remaining is to refine the diagnostic characteristics of diet responders and delineate what percent of the ADHD population they constitute. Though half or more of enriched samples selected for suspicion of food sensitivity seem to respond well under controlled conditions, it is not clear what proportion this represents of the whole ADHD population. Preliminary evidence suggests that the profile of a probable responder is a middle- or upper-class preschooler with atopy and prominent irritability and sleep disturbance, with physical as well as behavioral symptoms, and possibly high copper levels (Brenner, 1979), but the definition needs more work.

A related dietary strategy, simple elimination of sugar or candy, has not garnered convincing scientific support from repeated placebo-controlled acute challenge studies (Krummel, Seligson, \& Guthrie, 1996; Wolraich, Wilson, \& White, 1995) despite a few encouraging reports (e.g., Goldman, Lerman, Contois, \& Udall, 1986). Even a well-controlled 3-week trial of a sugar-restricted diet found no effect (Wolraich, Lindgren, Stumbo, Stegink, Applebaum, \& Kiritsy, 1994). Further, most cross-sectional comparisons have not shown excess consumption of sugar by children with ADHD compared to controls (Kruesi, Rapoport, Berg, Stables, \& Bou, 1987; Wolraich, Stumbo, Milch, Chenard, \& Schultz, 1986; Kaplan, McNicol, Conte, \& Moghadam, 1989b), though some have found correlations between dietary sugar or refined carbohydrate intake and measures of hyperactivity, aggression, or inattention/cognition in children either with ADHD (Prinz, Roberts, \& Hantman, 1980; Wolraich et al, 1986) or unselected for ADHD (Lester, Thatcher, \& Monroe-Lord, 1982). It does not appear that sugar or candy restriction alone is a widely applicable treatment for ADHD, though it is conceivable that continued sugar/candy elimination partially contributes to the documented benefit of the few-foods diet for some children with ADHD.

The side effects, risks, and ripple effects of dietary eliminations remain as controversial as the diets themselves. For example, Krummel et al. (1996) warn that coercively enforced parental restrictions on the child's diet (or putting the rest of the family unnecessarily on the same diet) could worsen family dynamics while Lipton and Mayo (1983) say the nonspecific placebo effects are beneficial to families. There is some concern about breadth of nutrient intake on the one hand, and on the other hand the comment that eliminating junk foods improves essential nutrient intake (Rimland, 1983). On balance, it seems the main risk associated with dietary elimination is the delay of more effective treatment if the child is a nonresponder. 


\section{Immune Therapy}

Food-borne allergy may not be the only immunological consideration for etiological subgroups of ADHD. In 50 children (mean age 9) with pediatric autoimmune disorders associated with streptococcal group A beta-hemolytic infection (PANDAS), Swedo et al. (1998) found a 40 percent rate of ADHD. It is not clear what proportion of an unselected ADHD sample would have PANDAS. However, Hagerman and Falkenstein (1987) reported twice the rate of otitis media in hyperactive subjects compared to controls, suggesting either immune problems or greater exposure to infectious agents. Swedo et al. planned a trial of immune therapy as Tx of the neuropsychiatric disorders, but no results are available as of this writing. Immunological therapy targeting Candida (Palacios, 1976, 1977) might be a logical alternative to antifungal therapy for hypothesized sensitivity to gastrointestinal yeast overgrowth, but apparently has not been proposed for ADHD. For food sensitivities, Egger et al. (1992) have reported significant ( $p<$ 0.001 ) benefit from enzyme-potentiated desensitization in a double-blind placebo-controlled trial.

\section{Nutritional Supplements}

In a sense, nutritional supplementation is the opposite of elimination or few-foods diets, which are based on the assumption that something in the diet is noxious and should be removed. Supplementation is based on the assumption that something is lacking in the diet in optimal amount and should be added. Both macronutrients (amino acids, lipids, carbohydrates) and micronutrients (vitamins and minerals) have been proposed as Tx for ADHD.

\section{Amino Acid Supplementation}

Amino acid supplementation is theoretically supported by report of low levels of amino acids in ADHD, including the precursors of catecholamines and serotonin (Bornstein, Baker, Carroll, King, Wong, \& Douglass, 1990; Baker, Bornstein, Rouget, Therrien, \& van Muyden 1991). Stein and Sammaritano (1984) reported that compared to matched normals with similar dietary intake, 8- to 10-year-old hyperkinetic boys excreted more nitrogen (JES = 5, $p<0.01$ ) and showed different distribution patterns of excretion, flux, and protein synthesis. Several open and controlled studies have reported a short-term benefit from tryptophan, tyrosine, or phenyalanine supplementation (Nemzer, Arnold, Votolato, \& McConnell, 1986; Reimherr, Wender, Wood, \& Ward, 1987; Wood, Reimherr, \& Wender, 1985a). However, no lasting benefit beyond 2-3 months has been demonstrated since tolerance usually develops (Wood, Reimherr, \& Wender, 1985b), and even short-term benefit was not found in some studies (Eisenberg, Asnis, van Praag, \& Vela, 1988; Ghose, 1983; Zametkin, Karoum, \& Rapoport, 1987). Further, such supplementation, while originally considered benign, may carry some risk (Pakes, 1978; Sidransky, 1997; Sternberg, 1996). The best-publicized risk was the 1989 epidemic of eosinophilia-myalgia linked to tryptophan use. However, this association was more likely due to impurities rather than to the tryptophan itself (Sidransky, 1997; Williamson, Tomlinson, Mishra, Gleich, \& Naylor, 1998), and it may have partly resulted from circular diagnostic practice (Blackburn, 1997; Wagner, Elmore, \& Horwitz, 1996). In sum, amino acid supplementation does not appear a promising area to explore further, though protein-rich diets might be explored as a specific correction of the reported nitrogen-wasting metabolic aberrations or as palliation of alleged hypoglycemia.

\section{Essential Fatty Acid Supplementation}

Neuronal membranes are composed of phospholipids containing large amounts of polyunsaturated fatty acids, especially the n-3 and n-6 (or omega-3 and omega-6) acids (with the 
first unsaturated bond 3 or 6 carbons, respectively, from the noncarboxyl "tail" of the molecule), which humans cannot manufacture de novo and hence are "essential" in the diet. Essential fatty acids (EFA) are also metabolized to prostaglandins and other eicosanoids, which modify many metabolic processes. Lab animal behavior can be manipulated by varying the quantity and quality of essential fatty acids (Arnold, Kleykamp, Votolato, Gibson, \& Horrocks, 1994). Juvenile and young adult monkeys with long-term n-3 fatty acid deficiency show increased activity, and both human and monkey infants show changes in visual attention with n-3 deficiency (Neuringer, 1998). In adult humans, n-6 EFAs correlated positively and n-3 EFAs correlated negatively with cerebral-spinal-fluid 5-HIAA and HVA, the metabolites respectively of serotonin and dopamine (Hibbeln, Linnoila, Umhau, Rawlings, George, \& Salem, 1998). Both the n-3 series (progenitor alpha-linolenic acid) and the n-6 series (progenitor linolenic acid) have been reported to be significantly lower in children with ADHD than in comparison controls (Mitchell, Lewis, \& Cutler, 1983; Mitchell, Aman, Turbott, \& Manku, 1987; Stevens et al., 1995). Even total serum free fatty acids were lower in ADHD, with $E S=2.4, p<.001$ (Bekaroglu et al., 1996). Aggression has been significantly inhibited in young adults by docosohexaenoic acid of the n-3 series (Hamazaki et al., 1996). Two double-blind placebo controlled trials of gamma-linolenic acid (n-6 series, evening primrose oil) supplementation yielded equivocal results from ADHD subjects not selected for low n-6 acids (Aman, Mitchell, \& Turbott, 1987; Arnold, Kleykamp, Votolato, Taylor, Kontras, \& Tobin, 1989); in one trial, the serum triglyceride gamma-linolenic acid correlated inversely with Conners Rating Scale scores (Arnold et al., 1994). A controlled pilot trial of n-3 supplementation in ADHD subjects selected for symptoms of EFA deficiency (but not for specific n-3 deficiency in plasma) showed a trend of advantage for the supplement despite a huge placebo effect (pre-post $E S 1.8$ vs. 1.4), and changes in serum phospholipid n-3 acids correlated negatively with changes in Conners Rating Scale scores (Burgess \& Stevens, 1998). In preliminary data on 70 subjects not selected for deficiency, Voight, Llorente, Jensen, Berretta, Boutte, and Heird (1998) found no effect of docosohexaenoic acid (n-3) compared to placebo. In sum, the data suggest further controlled trials in patients selected for low serum levels of the specific EFA supplemented.

\section{Glyconutritional Supplements}

Glyconutritional supplement contains basic saccharides necessary for cell communication and formation of glycoproteins and glycolipids: glucose, galactose, mannose, $\mathrm{N}$-acetylneuraminic acid, fucose, $\mathrm{N}$-acetylgalactosamine, and xylose. Only the first two are abundant in the ordinary diet. In an open trial of glyconutritional and phytonutritional (flash freeze-dried fruits and vegetables) supplementation with 17 ADHD subjects, Dykman and Dykman (1998) found significant $(p<.05-p<.001)$ reductions in parent SNAP-IV ratings of inattention, hyperactivity-impulsivity, and oppositional symptoms, with similar trends on teacher ratings. In a second open trial of the same supplements in 18 children, Dykman and McKinley (1997) found reductions in parent inattention ratings from 2.47 to $2.05(p<.06)$ and hyperactivity-impulsivity ratings from 2.23 to 1.54 ( $p<.003$ ), sustained for 6 weeks. Placebo-controlled trials are needed.

\section{Vitamin Supplementation}

Three strategies for vitamin supplementation are: 1. RDA multivitamin preparations; 2. Megavitamin multiple combinations; and 3- Megadoses of specific vitamins.

The first strategy is noncontroversial but there is no research on effects in diagnosed ADHD even though some reports suggest mild deficiencies in diet and blood levels that might be addressed. However, in a randomly assigned double-blind placebo-controlled trial of RDA 
vitamin and mineral supplementation in 47 6-year-old children not selected for ADHD, Benton and Cook (1991) found an 8.3-point IQ advantage $(p<.001)$. This IQ advantage is represented mainly in nonverbal ability, increased concentration and decreased fidgeting on a frustrating task $(p<.05)$, and advantage on a reaction time task reflecting sustained attention $(E S=1.3, p<.05)$. These data warrant a controlled trial in ADHD, although the benefit may be confined to a subgroup with poor diets (Benton \& Buts, 1990).

The second strategy, megavitamin multiple combinations, has not been found effective in double-blind placebo-controlled short (2 week) and longer (up to 6 month) trials examining ADHD and the related comorbidity of learning disorder (Arnold, 1978; Haslam, Dalby, \& Rademaker, 1984; Kershner \& Hawke, 1979). The researchers who conducted those trials have been challenged on the basis of not using the correct mix of vitamins and minerals. Also, Kershner and Hawke's (1979) study used a preliminary elimination diet that removed so much deviance that the vitamin trial suffered from a ceiling effect. On balance, megavitamin multiple combinations do not seem worth pursuing.

The third strategy, judicious use of single vitamins in megadosage to alter neural metabolism in specific ways, is actually more like psychopharmacology and has not been adequately explored despite some encouraging early reports (e.g., Coleman et al., 1979; Brenner, 1982).

Though megavitamins, like any pharmacological intervention, pose some risk, the hepatotoxic (Haslam et al., 1984; Shaywitz, Seigel, \& Pearson, 1977), neuropathic (Schaumburg et al., 1983; Bernstein, 1990; Snodgrass, 1992), and other (Sato, Taguchi, Maeda, \& Yoshikawa, 1993; Snodgrass, 1992; Anonymous, 1984) dangers may be overstated in some quarters: the hepatotoxicity reported by Shaywitz et al. (1977) resulted from accidental overdosage of vitamin A, not from megavitamin therapy; the doses of pyridoxine (B6) reported to cause neuropathy (generally $2 \mathrm{~g}$ or more a day) are higher than the doses usually recommended in most megavitamin regimens; and pyridoxine toxicity seems largely reversible on cessation of supplementation. In intermediate doses (e.g., 100-150 mg/day), pyridoxine is more likely to counteract toxicity of other ingestants, including drugs, food colors, and excess other nutrients than to be toxic itself (Brown, Mallett, Fiser, \& Arnold, 1984; Bernstein, 1990; Houben \& Penninks, 1994; Durlach, Durlach, Bac, Bara, \& Guiet-Bara, 1994). Except for rare genetic disorders, RDA multivitamins do not appear to pose any risk other than sensitivity to added coloring or flavors.

\section{Mineral Supplements}

The main mineral candidates for supplementation are iron, zinc, magnesium, and calcium, all of which have been reported deficient in subjects with ADHD compared to matched controls (Kozielec, Starobrat-Hermelin, \& Kotkowiak, 1994).

\section{Iron Supplementation.}

Iron is a co-enzyme in anabolism of catecholamines. In an open 30-day supplementation trial with 17 nonanemic ADHD boys age 7-11, Sever, Ashkenazi, Tyano, and Weizman (1997) found improvement in Conners Rating Scale parents' scores from 17.6 to 12.7 (ES = 1.0), but not in teacher ratings. In a double-blind placebo-controlled trial in 73 teenage nonanemic but iron-deficient girls, Bruner, Joffe, Duggan, Casella, and Brandt (1996) found improvements in verbal learning and memory. In a trial of gastroprotected ferritin in 33 iron-deficient children, Burattini et al. (1990) found a decrease of hyperactivity. Iron supplementation merits further study, with focus on whether any benefit found is confined to those with laboratory evidence of iron deficiency, and with due concern for possible toxicity of excess iron. 


\section{Zinc Supplementation.}

Zinc is a cofactor for 100 enzymes, many involved in neural metabolism, and is necessary for fatty acid absorption and for production of melatonin, which helps regulate dopamine function (Sandyk, 1990). Animal data suggest involvement of zinc deficiency in hyperactivity (e.g., Halas \& Sandstead, 1975; Sandstead, Fosmire, Halas, Jacob, Strobel, \& Marks, 1977), and human deficiency syndrome includes concentration impairment and jitters (Aggett \& Harries, 1979). Zinc has been reported deficient in ADHD compared to controls, with ES up to 2.4 ( $p<.001$ ) (Bekaroglu et al., 1996; Toren et al, 1996). However, McGee, Williams, Anderson, McKenzie-Parnell, and Silva (1990) did not find a significant correlation of parent and teacher hyperactivity ratings with hair or serum zinc in the epidemiologic Dunedin sample. Arnold, Votolato, Kleykamp, Baker, and Bornstein (1990) reported data suggesting that stimulant response may depend on adequate zinc nutriture. Sandyk (1990) speculated that stimulants might work via their reported propensity for increasing melatonin production, a process dependent on zinc. Despite clinical advocacy of zinc supplementation, no systematic prospective trials could be found. The obvious need is a placebo-controlled double-blind trial of RDA zinc supplementation with pre-treatment assessment of zinc status to determine whether zinc deficiency is a prerequisite for any benefit found. Though excess zinc can cause white cell aplasia (Forsyth \& Davies, 1995), this does not appear to be a risk for RDA doses.

Magnesium Supplementation.

Magnesium deficiency can cause a wide spectrum of neurological and psychiatric disturbance and can result from a wide variety of causes, including increased requirement during childhood (Flink, 1981). Kozielec and Starobrat-Hermelin (1997) examined hair, red cell, and serum magnesium of 116 children age 9-12 with ADHD and found 95 percent (34 percent by serum alone) deficient in magnesium; there was no control group other than lab norms. They assigned 50 children age 7-12 with DSM-IV ADHD and magnesium deficiency to 6 months open supplementation with about $200 \mathrm{mg} /$ day (in addition to usual treatment) and 30 similar controls were assigned to usual treatment without magnesium; it was not clear whether assignment was random; the supplemented group significantly decreased their Conners' Rating Scales parent and teacher ratings ( $E S=1.2-1.4$ ) compared to the control group (Starobrat-Hermelin \& Kozielec, 1997). Thus, magnesium supplementation merits a randomized placebo-controlled double-blind trial and replication by other investigators. Dosage of supplementation may be important, because animal work suggests a U-shaped behavioral dose-response curve (Izenwasser, 1986). Therefore, it is possible that children not deficient in magnesium could be made worse by supplementation. Further, doses $>10 \mathrm{mg} / \mathrm{kg} /$ day can cause toxic symptoms (Durlach et al., 1994).

\section{Herbal and Homeopathic Treatments}

Many herbal and homeopathic remedies have been proposed for use in ADHD. No systematic data regarding ADHD efficacy could be found for Calmplex, Defendol, Gingko biloba, hypericum, or pycnogenol. Although a case report of successful pycnogenol treatment was found (Heimann, 1999), a representative of one of the companies selling pycnogenol said they had dropped ADHD as an indication because it doesn't work on ADHD. The first few remedies listed may be worth pilot trials based on clinical experience. There are more data for traditional Chinese herbals.

In a randomly assigned open trial, Zhang and Huang (1990) compared a Chinese herbal cocktail (80 Ss) to methylphenidate 5-15 mg b.i.d. (20 Ss) for 1-3 months; 23/80 herbal cocktail 
cases were "cured" (disappearance of all clinical symptoms and no recurrence for 6 months) compared to 6/20 taking methylphenidate. Including improved cases, the effectiveness rates were 86 percent vs. 90 percent; the groups did not differ except for lower side effects and greater IQ rise in the herbal group. In an open trial with 100 hyperkinetic children, Wang, Li, and Li (1995) found an effectiveness rate of 94 percent, including reduction of hyperactivity, improved attention, and improved academics resulting from the administration of the herbal Tiaoshen Liquor. In another open trial in 66 hyperkinetic children, Sun, Wang, Qu, Wang, Fang, and, Zhang (1994) found an effectiveness rate of 85 percent with Yizhi wit-increasing syrup, including significant improvement in behavior, school records, and soft neurological signs. Shen and Wang (1984) reported that 8 children with minimal brain dysfunction showed the same decrease in urinary 3-methoxy-4-hydroxyphenylglycol from Chinese herbal treatment as 38 children did from methylphenidate. Thus, the open pilot data warrant placebo-controlled double-blind trials of Chinese herbals.

\section{Acupuncture}

Despite the popularity of acupuncture, no published systematic data on its efficacy with ADHD could be found. Loo (1998), in unpublished, preliminary, pre-post, single-blind data from students in grades K-3, found improvements in Conners' Rating Scale 10-item scores by teachers $(n=7)$ from 17.0 to 12.0 , and in analogous parent scores $(n=6)$ from 23.1 to 15.5. She noted that children with the most severe ADHD could not cooperate with the Tx.

\section{EEG Biofeedback}

Electroencephalographic (EEG) biofeedback involves inducing sensorimotor 12-15 Hertz or 15-18 Hertz beta band EEG rhythms and suppressing theta rhythms by visual and auditory feedback. Research into the efficacy of EEG biofeedback with ADHD arose from 1) the observation that some ADHD children have more theta and less beta rhythm than controls and 2) animal work that demonstrated reduced motor activity associated with sensorimotor rhythm (Shouse \& Lubar, 1978; Mann, 1992). There are several promising pilot trials. Lubar (1991) and Lubar and Shouse (1977) reported that in a single-subject ABA design, 4 hyperactive children selected for low arousal showed better behavior and work habits without stimulant at the end of all treatment (ABA) than at the beginning with or without stimulant and their unmedicated level of undesirable behaviors dropped by over half to the level of the normal controls; three of them showed synchrony of behavior with the ABA shifts. An uncontrolled open trial with 37 hyperactive children yielded significant grade-point and achievement score improvements (Lubar, 1991). In an intensive summer treatment regimen, 12 children who showed EEG changes also improved on significantly more Tests of Variables of Attention scales than did 7 who failed to show EEG changes (Lubar, Swartwood, Swartwood, \& O'Donnell, 1995). Linden, Habib, and Radojevic (1996) randomly assigned 18 children with DSM-IIIR ADD/ADHD to either a waiting list $(n=9)$ or to 40 EEG biofeedback sessions over a 40 -week period. The treated group showed a 9-point IQ rise compared to the waiting list rise of $<1$ point $(p<0.05)$ and a 28 percent reduction on the inattention score of the SNAP (Swanson, Nolan, and Pelham scale with DSM ADHD symptoms on Conners metric) compared to a 4 percent increase for the waiting list group $(p<.05)$. Thus, this treatment merits a sham-controlled randomized trial (Arnold, 1995).

\section{EMG Biofeedback, Relaxation Training, and Hypnosis}

These three related Tx modalities are typically used in some combination. The few published data on hypnotherapy alone for treatment of ADHD are discouraging: Calhoun and 
Bolton (1986) were unsuccessful in three attempts each to hypnotize 10 of the 11 hyperactive children they tried it with. Breathing control alone, used not only in hypnosis but also in meditation and relaxation, showed no difference from sham training in 6 hyperactive intelligent 6-8-year-olds (Simpson \& Nelson, 1974). However, the hypnotic techniques of imagery and progressive relaxation have often been incorporated into successful EMG biofeedback protocols.

There are more literature citations for EMG than for EEG biofeedback (Lee, 1991), but they are generally older, suggesting a recent waning of interest. Denkowski, Denkowski, and Omizo (1983) randomly assigned hyperactive junior high school boys to six 25-minute EMG-assisted relaxation training sessions $(n=24)$ or to a control condition $(n=24)$; the treated group attained significantly higher reading and language performance and made a significant internal shift in locus of control. In 10 hyperactive boys age 6-12, Dunn and Howell (1982) found significant improvement in behavior observations, parent ratings, and psychological tests after 10 relaxation training sessions but none after 10 neutral sessions. Omizo and Michael (1982) randomly assigned hyperactive boys age 10-12 to either four sessions of EMG biofeedback-induced relaxation $(n=16)$ or sham treatment $(n=16)$ of equal length; compared to the sham, the relaxation induced significant improvements in attention and impulsivity as indicated from results on the Matching Familiar Figures test ( $E S=1.0$ to $1.3, p<.01$ ). Krieger (1985) found in 27 children age 7-11 with DSM-III Attention Deficit Disorder-Hyperactivity (ADD-H) significant improvement on Conners' parent and teacher rating scales compared to an equal-n matched wait list control group. Success is largely moderated by baseline locus of control (Denkowski et al., 1984). However, the reports were not uniformly positive; Irving (1987) found in 24 boys age 6-12 that EMG biofeedback/relaxation added nothing to stimulant benefit, but stimulant added to biofeedback benefit. Denkowski and Denkowski (1984) assigned 45 hyperactive elementary school children to eight sessions of group progressive relaxation training, relaxation training with frontalis biofeedback, or placebo (listening to taped children's stories); the trend of advantage for the two active treatments was not significant at the group size of 15. Cobb and Evans (1981) reviewed the then extant literature and concluded that there was no evidence that biofeedback was superior to "more conventional treatments" for learning or behavior disorders. Nevertheless, the data on balance suggest that despite recent neglect, EMG biofeedback-facilitated relaxation training merits further study for children with ADHD who do not benefit from stimulants or whose parents object to stimulants.

\section{Meditation}

Meditation, though resulting in relaxation, is different from the preceding treatments in not directly targeting relaxation, but achieving it indirectly. Kratter (1983) randomly assigned 24 children age 7-12 with DSM-III ADD-H to either meditation training, progressive relaxation, or waiting list control, with 4 weeks of twice-weekly sessions; both active treatments but not waiting list reduced impulsivity and improved scores on parent behavior scales but not teacher scales; only meditation training showed significant improvement on a test assessing selective attention. Moretti-Altuna (1987) randomly assigned 23 boys age 6-12 with ADD-H to meditation training, medication, or standard therapy; meditation showed significant advantage in classroom behavior but not in parent ratings or psychological tests. Thus, meditation warrants further study.

\section{Mirror Feedback}

Mirrors have been proposed as a way of increasing self-control and attentional focus by increasing self-focus in children with ADHD (Zentall, Hall, \& Lee, 1998). In a single-blind randomized trial on 16 hyperactive-inattentive (HI) and 27 normal middle-school students, a word 
puzzle that differentiated the HI from the control subjects with an effect size of $0.75(p<.05)$ in the no-mirror condition showed a between-groups ES of only 0.2 (n.s.) with a mirror in front of the child as he/she worked. The mirror condition improved the performance of the HI Ss by half the no-mirror difference between groups. With no instruction about the mirror, the His who actually looked in the mirror scored equal to the no-mirror scores of the controls. This intervention carries a risk associated with diagnostic validity: the normal controls showed a trend of performance decrement with the mirror, especially if they looked in it (Zentall et al., 1998). Though not applicable to a regular classroom, it may be useful in learning carrels specifically used by ADHD students and for homework, and deserves further trials.

\section{Perceptual Stimulation/Training}

Perceptual and sensory stimulation and training include a wide variety of modalities, some with few or no data. The literature search found no systematic data on sensorimotor integration or optometric training for ADHD despite their widespread use. Neither were studies in ADHD found for massage, which has documented efficacy in other applications (Field, Morrow, Valdeon, Larson, Kuhn, \& Schanberg, 1992). The Interactive Metronome (1998) provides perceptual-motor concentration training with biofeedback about accuracy from motion sensors as the child taps to the beat provided by the program; open trials show improvements in timing that correlate at 0.2-0.4 with teacher ratings of attention, but there are no controlled data (Interactive Metronome, 1998).

In a single-blind prevention paradigm, Arnold et al. (1977) randomly assigned matched trios and quads of first-graders selected for vulnerability on a perceptual screening battery to either 6 months of channel-specific perceptual training $(n=23)$, the same length of regular academic tutoring $(n=23)$, or to no-contact control $(n=40)$; at 1-year follow-up, the trained group surpassed both control groups in blinded teacher Conners' ratings ( $E S=1.0, p<.01)$, Wide Range Achievement Test (WRAT) reading achievement (12.6 standard points difference, $p<0.01$ ), and Wechsler IQ (8 points difference, $p<0.05$ ), though baseline measures were not different.

Mulligan (1996) reported significant impairment of vestibular processing in 309 children with ADHD compared to 309 matched children without ADHD $(p<0.01)$. Both the semicircular canals and the otolithic utricles/ saccules of the vestibular system activate the autonomic nervous system (Yates, 1992). Previc (1993) suggests that the utricles/otoliths produce noradrenergic sympathetic brain stimulation while the semicircular canals produce cholinergic parasympathetic brain stimulation. In a single-blind crossover in 18 children with DSM-II hyperkinetic reaction, Bhatara, Clark, Arnold, Gonsett, and Smeltzer (1981) found improvement in Conners' teacher ratings from rotational vestibular stimulation of the semicircular canals compared to a sham condition $(p<.05)$, with benefit mainly confined to the 14 children below age 10 and those without comorbid conduct disorder. In another single-blind crossover with 12 children identified through teacher scale screening, Arnold, Clark, Sachs, Jakim, and Smithies (1985) found an ES of 0.5 between vestibular rotational stimulation alone and two control conditions (missing significance at the sample size), compared to an $E S$ of 0.2 between visual rotational stimulation alone and the same control conditions in a similar group of 18 children. The Comprehensive Motion Apparatus provides vestibular stimulation in all vectors through complex motion, stimulating both semicircular canals and otoliths; an open trial in 14 dyslexic children (mean age $12 \pm 2.6$ yr.) showed pre-post improvement in parent rating of attention $(E S=1.5, p<.003)$ and objective cognitive/achievement tests (ES 0.4-1.2, p 0.05-0.001) (Stillman, 1998). Thus, stimulation and/or training of specific perceptual channels merits further research in controlled trials, especially targeting subgroups who test deficient in the particular perceptual modality. 


\section{Antifungal Treatment}

Treatment with antifungal agents such as nystatin (in combination with sugar restriction and other measures) is advocated by Crook (1985, 1989, 199D and others on the hypothesis that repeated antibiotic use for otitis media changes intestinal flora, allowing yeast overgrowth, which compromises immune function and changes the gut mucosal barrier to allow absorption of food antigens. Several components of this hypothesis are supported by collateral documentation from other fields (e.g., Hagerman \& Falkenstein, 1987; Nsouli, Nsouli, Linde, O'Mara, Scanlon, \& Bellanti, 1994; Vargas, Patrick, Ayers, \& Hughs, 1993), and the hypothesis would make sense of the reported association of chronic sugar intake with ADHD symptoms (e.g., Prinz et al., 1980) without acute effects, in that sugar could promote yeast overgrowth chronically without showing acute effects on behavior. However, this hypothesis is not supported by any systematic prospective trial data in ADHD. A trial of nystatin alone for fatigue, premenstrual tension, gastrointestinal symptoms, and depression associated with Candida vaginitis was reported negative (Dismukes, Wade, Lee, Dockery, \& Hain, 1990); but Crandall (1991) challenged this conclusion on methodological grounds and Truss (1991), reanalyzing the published crossover data, found an advantage for double nystatin (oral and vaginal) over double placebo significant at $p<0.01$ (2-tailed). A systematic randomly assigned trial in ADHD should be carried out, preferably double-blind placebo-controlled and accompanied by the sugar restriction and other supportive measures recommended by the advocates of this treatment.

\section{Thyroid Treatment}

Despite initial enthusiasm about resistance to thyroid hormone as a key to a large proportion of ADHD, this genetic syndrome appears extremely rare in ADHD samples. The same studies, however, reveal a rate of other thyroid dysfunction ranging from 2 percent to 5 percent (e.g., Weiss, Stein, Trommer, \& Refetoff, 1993; Valentine, Rossi, O'Leary, Parry, Kurinczuk, \& Sly, 1997), and the rate may be higher in those with comorbid mood disorder (West et al., 1996). In children with thyroid dysfunction, the thyroid status seems related to attentional and hyperactive-impulsive symptoms (Rovet \& Alvarez, 1996; Hauser, Soler, Brucker-Davis, \& Weintraub, 1997). In a double-blind placebo crossover trial of thyroid supplementation, only 1 of 9 children with ADHD and normal thyroid function improved compared to 5 of 8 with ADHD and resistance to thyroid hormone (Weiss, Stein, \& Refetoff, 1997). Thus, thyroid treatment does not seem promising in ADHD children with normal thyroid function, but would seem the treatment of choice for those with thyroid dysfunction. Therefore, all children with ADHD should be screened for historical and physical exam signs of possible thyroid dysfunction (Weiss \& Stein, 1998).

\section{Deleading}

Animal data (e.g., Silbergeld \& Goldberg, 1975) document hyperactivity as one symptom of chronic lead poisoning, and suggest that lead-induced hyperactivity depends on lead levels and can be reversed by chelation (Gong \& Evans, 1997). In humans (e.g., David, Hoffman, Sverd, \& Clark, 1977) the blood level considered toxic for subtle neuropsychiatric symptoms has declined with increasing knowledge: in 1991 the Centers for Disease Control adopted $10 \mu \mathrm{g} / \mathrm{dL}$ for developing children, and some authors place it as low as single digits (Kahn, Kelly, \& Walker, 1995). Whether or not tissue lead levels correlate with behavioral and cognitive measures is the subject of some controversy, partly depending on the sample size, consequent power, and range of lead burden in the population studied (Gittleman \& Eskanazi, 1983; Needleman et al., 1979). David, Hoffman, Sverd, Clark, and Voeller (1976) openly treated 13 children who had 
hyperkinetic reaction and blood lead levels $>25 \mu \mathrm{g} / \mathrm{dL}$ with penicillamine (CaEDTA if allergic to penicillin); the 7 with no other probable medical cause of their hyperkinesis improved in teacher hyperactivity rating $(E S=1.4, p<0.01)$ and parent hyperactive-impulsive rating $(E S=2.2, p<$ $.0 .05)$, but not significantly in teacher inattention rating $(E S=0.6)$, while the 6 with another probable medical cause did not improve. In a double-blind placebo-controlled 12-week trial, David, Hoffman, Clark, Grad, and Sverd (1983) randomly assigned hyperactive children with "minimally elevated lead levels" (mean $28 \pm 6 \mu \mathrm{g} / \mathrm{dL}$ ) to either penicillamine plus methylphenidate placebo $(n=22)$, methylphenidate (5-40 mg/day) plus penicillamine placebo $(n=11)$, or double placebo $(n=11)$ : compared to placebo, penicillamine improved Conners' teacher hyperactivity scores $(E S=1.6, \mathrm{p}<0.001)$, parent Werry-Weiss-Peters hyperactivity scores $(E S=0.7, p<0.05)$, and Clinical Global Impression $(E S=1.4, \mathrm{p}<0.01)$; across measures the penicillamine group did nonsignificantly better than the methylphenidate group. Thus, it appears that deleading would be the treatment of choice for children with ADHD who have blood lead elevations in the range treated by David and associates. How low a blood lead level this treatment should extend to is a research question of high priority.

\section{Recommendations for Clinical Practice}

There seem to be four categories of alternatives in treating ADHD (alternatives being defined as treatments other than psychoactive medication and psychosocial/behavioral treatments).

\section{Category 1}

Many of the treatment alternatives for ADHD are in various stages of scientific exploration, ranging from hypothesis through pilot data, and therefore do not enjoy the data base necessary for making clinical practice recommendations. These treatments are neither proven nor found lacking in definitive controlled trials. Included in this category are essential fatty acid supplementation, glyconutritional supplementation, RDA vitamins, single-vitamin megadosage, herbals, homeopathic remedies, Laser acupuncture, EEG biofeedback, mirror feedback, channel-specific perceptual training, vestibular stimulation, antifungal therapy, and some types of immune therapy.

\section{Category 2}

A few of the alternatives proposed have been demonstrated to be probably ineffective or possibly dangerous. Prominent among these are the various forms of megavitamin multiple combinations (as opposed to RDA multivitamins) which have not only failed to show benefit in controlled studies, but also carry a mild risk of hepatotoxicity and peripheral neuropathy. Thus, megavitamin multiple combinations have enough evidence to warn physicians and the public away from their indiscriminate use. Megadosage of one or two specific vitamins may be more effective, but has not been adequately explored for ADHD. Amino acid supplementation (except for remedy of specific deficits), though possibly effective in the short term, does not seem to be a practical long-term treatment; there may also be some risk. Simple sugar restriction has not been found effective in most controlled studies, but does not appear to pose any risk.

\section{Category 3}

Some of the alternatives are ineffective or dangerous for the majority of children with ADHD, but clearly indicated by clinical common sense for those with the etiology targeted. For example, chelation ("deleading") would be the preferred treatment for patients with demonstrated 
blood elevations of lead (or other heavy metals), but would be irrelevant (at our current state of knowledge) and pose some risk for a child with blood lead below $10 \mu \mathrm{g} / \mathrm{dL}$. For the 2-5 percent of children with ADHD who have thyroid abnormality, correction of the thyroid problem should logically be the first line of treatment, but is not indicated for the majority with normal thyroid function. For children with demonstrated deficiencies of any nutrient (e.g., zinc, iron, magnesium, vitamins), correction of that deficiency is the logical first-line treatment. It is not clear what proportion of children have such a nutritional deficiency, but it may be higher than generally suspected because of the confluence of two factors: 1) Many children have a preference for highly processed sugary foods lacking in nutritional balance and succeed in subsisting on these despite parents' intentions to the contrary, and 2) many pediatricians and parents subscribe to the axiom that if one eats a balanced diet, vitamin supplementation is not necessary; since they intend for their children to eat a balanced diet, they overlook the first factor and conclude that vitamin pills are not necessary.

\section{Category 4}

A few of the alternatives have rather convincing scientific evidence or other features suggesting that they should be implemented where appropriate and practical. Chief among these is the few foods (oligoantigenic) diet, for which there is good evidence of efficacy in the subgroup with sensitivity to foods. Note that the proportion of diagnosed ADHD children who have food sensitivities has not been empirically established, but is certainly a minority, perhaps as low as 5 percent, but more likely double digits. The diet can be rather onerous, and the desensitization procedure may be more practical in many cases. A more generally applicable treatment with reasonable evidence of efficacy is the combination of relaxation training and EMG biofeedback, which is relatively inexpensive; some studies report results with only 4-8 sessions and group administration is feasible. Meditation, though not definitively proven in ADHD, has been reported beneficial in two small comparison trials and is accepted for other areas of health. It seems to carry no risk.

\section{Approach to Selecting Treatment}

Since many of the alternate treatments are targeted to specific etiologies, they should paradoxically be considered (not necessarily implemented) first during the diagnostic evaluation, which should consider etiologies for the symptoms. Only after etiologies amenable to specific treatment are ruled out should the standard, generic treatments (psychotropic medication and behavioral Tx) be implemented as the main therapeutic thrust. Therefore, a good history and physical exam will check for signs of thyroid dysfunction, allergic history, food intolerance, dietary balance/deficiency, and general medical problems. As individually indicated, a complete blood count and electrolytes/minerals are desirable as a general screen and to pick up mineral deficiencies. In areas with high rates of subclinical lead poisoning, a serum lead should be done. More complete screening for all minerals (e.g., iron, zinc) could be justified, especially if there is any question from the dietary history. In questionable cases, a therapeutic trial may be indicated.

\section{Recommendations for Future Research}

Future research efforts should a) mount definitive trials and replications of promising treatments that may have some advantage over the standard treatments if proven effective, b) mount controlled clinical trials of treatments for which a controlled trial is easy and cheap (Arnold, 1995), c) mount open pilot trials of well-considered hypotheses for which there are no pilot data and for which a controlled trial would be expensive or difficult, and d) define subgroups 
(characteristics and proportion of diagnosed ADHD children) appropriate for treatments for which efficacy has been demonstrated.

\section{Replications and Definitive Trials}

The following treatments have either promising enough pilot data to warrant a definitive clinical trial or a controlled study deserving replication by other investigators: Chinese herbals, EEG biofeedback, mirror feedback, channel-specific perceptual training, vestibular stimulation (e.g., comprehensive motion machine), magnesium supplementation, enzyme-potentiated desensitization for food allergies, meditation, and possibly n-3 essential fatty acid supplementation in patients with low plasma levels.

\section{Controlled Trials that are Cheap/Easy}

It would be easy enough and cheap enough to do a controlled trial of the following that it makes sense to take this step directly in order to settle the issue: glyconutritional supplementation, RDA multivitamins, zinc RDA supplementation, antifungal therapy (with sugar restriction).

\section{Pilot and Open Trials}

The following need some pilot data to tell whether a controlled clinical trial is indicated: homeopathic remedies, nonChinese herbals, acupuncture, chronic sugar restriction, massage.

\section{Definition of Applicable Subgroups of ADHD}

The following treatments, with either convincing controlled-trial evidence of efficacy or else common-sense clinical justification for appropriate patients, need better definition of the appropriate subgroups of ADHD patients: few foods (oligoantigenic) diets, chelation (what is the critical blood level of lead responsive to chelation?), iron supplementation (how iron-deficient, or is deficiency even needed?), EMG biofeedback/relaxation.

The most basic recommendation for future research on treatment alternatives for ADHD is that there should be more. Most of the alternatives have been relatively neglected by most mainstream investigators and by peer-reviewed funding, despite the fact that some of them could be relatively cheaply tested. This has three unfortunate consequences: 1) dogma (both establishment and anti-establishment) fills the void left by absence of data, 2) potentially useful treatments are rejected or neglected without a fair trial by clinicians who demand scientific validation, and 3) possibly ineffective or even dangerous treatments can be advocated without the data necessary to debunk them. This area needs more scientific attention.

\section{References} 909-917.

Agget, P.J., \& Harries, J.T. (1979). Current status of zinc in health and disease states. Arch. Dis. Child, 54,

Aman, M.G., Mitchell, E.A., \& Turbott, S.H. (1987). The effects of essential fatty acid supplementation by Efamol in hyperactive children. J. Abnormal Child Psychology, 15, 75-90.

Anonymous. (1984). Vitamin B6 toxicity: A new megavitamin syndrome. Nutrition Reviews, 42, 44-46.

Arnold, L.E. (1978). Megavitamins for MBD: A placebo-controlled study. J. American Medical Association,

20, 24.

Arnold, L.E. (1995) Some nontraditional (unconventional and/or innovative) psychosocial treatments for children and adolescents: critique and proposed screening principles. J. Abnormal Child Psychology, 23, 1, 125-140.

Arnold, L.E., Barnebey, N., McManus, J., Smeltzer, D., Conrad, A., Winer, G., \& Desgranges, L. (1977).

Prevention by specific perceptual remediation for vulnerable first-graders: Controlled study and follow-up of lasting effects. Archives of General Psychiatry, 34, 1279-1294.

Arnold, L.E., Clark, D.L., Sachs, L.A., Jakim, S., \& Smithies, C. (1985). Vestibular and visual rotational 
stimulation as treatment for Attention Deficit and Hyperactivity. American Journal of Occupational Therapy, 39 (2), 84-91.

Arnold, L.E., Kleykamp, D., Votolato, N., Gibson, R.A., \& Horrocks, L. (1994). Potential link between dietary intake of fatty acids and behavior: Pilot exploration of serum lipids in ADHD. J. Child \& Adolescent Psychopharmacology, 4(3), 171-180.

Arnold, L.E., Kleykamp, D, Votolato, N.A., Taylor, W.A, Kontras, S.B., \& Tobin, K. (1989).

Gamma-linolenic acid for Attention-Deficit Hyperactivity Disorder: Placebo controlled comparison to d-amphetamine. Biological Psychiatry, 25, 222-228.

Arnold, L.E., Votolato, N.A., Kleykamp, D., Baker, G.B., \& Bornstein, R.A. (1990). Does hair zinc predict amphetamine improvement of ADHD/Hyperactivity? Inter. J. Neuroscience, 50, 103-107.

Baker, G.B., Bornstein, R.A., Rouget, A., Therrian, S, \& van Muyden, J. (1991). Phenylethylaminergic mechanisms in Attention-Deficit Disorder. Biological Psychiatry, 29, 15-22.

Bekaroglu, M., Yakup, A., Yusof, G., Orhan, D., Hilal, M., Erol, E., \& Caner, K. (1996). Relationships

between serum free fatty acids and zinc and ADHD. J. Child Psychol. Psychiat. 37, 225-227.

Benton, D., \& Buts, J.P. (1990). Vitamin/mineral supplementation and intelligence. Lancet, 335, 1158-1160.

Benton, D., \& Cook, R. (1991). Vitamin and mineral supplements improve the intelligence scores and

concentration of six-year-old children. Personality and Individual Differences, 12, 1151-1158.

Bernstein, A.L. (1990). Vitamin B6 in clinical neurology. Annals of the New York Academy of Sciences, 585, 250-260.

Bhatara, V, Clark, D.L., Arnold, L.E., Gonsett, R., \& Smeltzer, D.J.(1981). Hyperkinesis treated by

vestibular stimulation: An exploratory study. Biological Psychiatry, 16 (3), 269-279.

Blackburn, W.D. Jr. (1997). Eosinophilia myalgia syndrome. Seminars in Arthritis and Rheumatism, 26, 788-793.

Boris, M., \& Mandel, F.S. (1994). Foods and additives are common causes of the attention deficit hyperactive disorder in children. Annals of Allergy, 72, 462-468.

Bornstein, R.A., Baker, G.B., Carroll, A., King, G., Wong, J.T., \& Douglass, A.B. (1990). Plasma amino

acids in attention deficit disorder. Psychiatry Research, 33, 301-306.

Breakey, J. (1997). The role of diet and behavior in childhood. J. Pediatrics and Child Health, 33, 190-194.

Brenner, A. (1979). Trace mineral levels in hyperactive children responding to the Feingold diet. $J$.

Pediatrics, 94, 44.

Brenner, A. (1982). The effects of megadoses of selected B complex vitamins on children with hyperkinesis; controlled studies with long-term follow-up. J. Learning Disabilities, 15, 258-264.

Brown, A., Mallett, M, Fiser, D., \& Arnold, W.C. (1984). Acute isoniazid intoxication: reversal of CNS symptoms with large doses of pyridoxine. Pediatric Pharmacology, 4, 199-202.

Bruner, A.B., Joffe, A., Duggan, A.K., Casella, F, \& Brandt, J. (1996). Randomized study of cognitive effects of iron supplementation in non-anemic iron-deficient girls. Lancet, 347, 992-996.

Burattini, M.G., Amendola, F., Aufierio, T., Spano, M., Di Bitonto, G., Del Vecchio, G.C., \& De Mattia, D. (1990). Evaluation of the effectiveness of gastro-protected proteofer-rin in the therapy of sideropenic anemia in childhood. Minerva Pediatrica, 42, 343-347.

Burgess, J.R., \& Stevens, L. (1998). Personal communication. Purdue University.

Calhoun, G. Jr, \& Bolton, J.A. (1986). Hypnotherapy: A possible alternative for treating pupils affected with Attention Deficit Disorder. Perceptual and Motor Skills, 63, 1191-1195.

Carter, CM., Urbanowicz, ML, Hemsley, R., Mantilla, L., Strobel, S, Graham, P.J., \& Taylor, E. (1993).

Effects of a few food diet in attention deficit disorder. Archives of Disease in Childhood, 69, 564-568.

Cobb, D.E., \& Evans, J.R. (1981). The use of biofeedback techniques with school-aged children exhibiting behavioral and/or learning problems. J. Abnormal Child Psychology, 9, 251-281.

Coleman, M., Steinberg, G., Tippett, J., Bhagavan, H.N., Coursin, D.B., Gross, M., Lewis, C, \& DeVeau, L. (1979). A preliminary study of the effect of pyridoxine administration in a subgroup of hyperkinetic children: A

double-blind crossover comparison with methylphenidate. Biological Psychiatry, 14, 741-751.

Conners, C.K. (1980). Food additives and hyperactive children. London: Plenum.

Crandall, M. (1991). A controlled trial of nystatin for the candidiasis hypersensitivity syndrome. (Letter to editor). New England Journal of Medicine.

Crook, W.G. (1985). Pediatricians, antibiotics, and office practice. Pediatrics, 76, 1.

Crook, W.G. (1989). The yeast connection (3rd ed.). Jackson, TN: Professional Books. 
Crook, W.G. (1991). A controlled trial of nystatin for the candidiasis hypersensitivity syndrome. (Letter to editor). New England Journal of Medicine.

David, O.J., Hoffman, S.P., Clark, J., Grad, G., \& Sverd, J. (1983). The relationship of hyperactivity to moderately elevated lead levels. Archives of Environmental Health, 38, 341-346.

David, O.J., Hoffman, S.P, Sverd, J., \& Clark, J. (1977). Lead and hyperactivity; lead levels among hyperactive children. J. Abnormal Child Psychology, 5, 405-416.

David, O.J., Hoffman, S.P, Sverd, J, Clark, J, \& Voeller, K. (1976). Lead and hyperactivity. Behavioral response to chelation: a pilot study. Amer. J. Psychiatry, 133, 1155-1158.

Denkowski, K.M., \& Denkowski, G.C. (1984). Is group progressive relaxation training as effective with hyperactive children as individual EMG biofeedback? Biofeedback and Self-Regulation, 9, 353-364.

Denkowski, K.M., Denkowski, G.C, \& Omizo, M.M. (1983). The effects of EMG-assisted relaxation training on the academic performance, locus of control, and self-esteem of hyperactive boys. Biofeedback and Self-Regulation, 8, 363-375.

Denkowski, K.M., Denkowski, G.C, \& Omizo, M.M. (1984). Predictors of success in the EMG biofeedback training of hyperactive male children. Biofeedback and Self-Regulation, 9, 253-264.

Dismukes, W.E., Wade, J.S., Lee, J.Y, Dockery, B.K., \& Hain, J.D. (1990). A randomized double-blind trial of nystatin therapy for the candidiasis hypersensitivity syndrome. New England Journal of Medicine, 323, 1717-1723.

Dunn, F.M., \& Howell, R.J. (1982). Relaxation training anc its relationship to hyperactivity in boys. $J$. Clinical Psychology, 38, 92-100.

Durlach, J., Durlach, V., Bac, P., Bara, M., \& Guiet-Bara, A. (1994). Magnesium and therapeutics. Magnesium Research, 7, 313-328.

Dykman, K.D., \& Dykman, R.A. (1998) Effect of nutrition al supplements on attentional-deficit hyperactivity disorder. Integrative Physiological and Behavioral Science, 33, 49-60.

Dykman, K.D., \& McKinley, R. (1997). Effect of glyconutritionals on the severity of ADHD. Proceedings of the Fisher Institute for Medical Research, 1 (1), 24-25.

Egger, J., Carter, CM., Graham, P.J., Gumley, D., \& Soothill, J.F. (1985). Controlled trial of oligoantigenic treatment in the hyperkinetic syndrome. Lancet, 540-545.

Egger, J., Stolla, A., \& McEwen, L.M. (1992). Controlled trial of hyposensitization in children with food-induced hyper kinetic syndrome. Lancet, 339.

Eisenberg, J., Asnis, G.M., van Praag, H.M., \& Vela, R.M. (1988). Effect of tyrosine on attention deficit disorder with hyperactivity. J. Clinical Psychiatry, 49, 193-195.

Feingold, B.E (1975). Why your child is hyperactive. New York: Random House. News, 2-3.

Feingold, B.F (1981). Refutes criticism of diet. (Reply to nutrition foundation report). Clinical Psychiatry

Field, T., Morrow, C, Valdeon, C, Larson, S., Kuhn, C, \& Schanberg, S. (1992) Massage reduces anxiety in child and adolescent psychiatric patients. J. Am. Acad. Child Adolesc. Psychiatry, 31, 1, 125-131

Flink, E.B. (1981). Magnesium deficiency. Etiology and clinical spectrum. Acta Medica Scandinavica -Supplementum, 647, 125-137.

Forsyth, P.D., \& Davies, J.M. (1995). Pure white cell aplasia and health food products. Postgraduate Medical Journal, 71, 557-558.

Ghose, K. (1983). L-tryptophan in hyperactive child syndrome associated with epilepsy: A controlled study. Neuropsychobiology, 10, 111-114.

Gittleman, R., \& Eskanazi, B. (1983). Lead and hyperactivity revisited: An investigation of nondisadvantaged children. Arch. Gen. Psychiatry, 40, 827-833.

Goldman, J.A., Lerman, R.H., Contois, J.H., \& Udall, J.N. Jr. (1986). Behavioral effects of sucrose on preschool children. J. Abnormal Child Psychology, 14, 565-511.

Gong, Z., \& Evans, H.L. (1997). Effect of chelation with meso-dimercaptosuccinic acid (DMSA) before and after the appearance of lead-induced neurotoxicity in the rat. Toxicology \& Applied Pharmacology, 144, 205-214.

Hagerman, R.J., \& Falkenstein, A.R. (1987). An association between recurrent otitis media in infancy and hyperactivity. 1 Clinical Pediatrics, 26, 253-257.

Halas, E.S., \& Sandstead, H.H. (1975). Some effects of prenatal zinc deficiency on behavior of the adult rat. Pediatric Research, 9, 94-97.

Hamazaki, T., Sawazaki, S., Itomura, M., Asaoka, E., Nagao, Y., Nishimura, N., Yazawa, K., Kuwamori, T., \& Kobayashi, M. (1996). The effect of docosohexaenoic acid on aggression in young adults. A placebo-controlled 
double-blind study. Clinical Investigation, 97, 1129-1133.

Haslam, R.H.A., Dalby, J.T., \& Rademaker, A.W. (1984). Effects of megavitamin therapy on children with attention deficit disorders. Pediatrics, 74, 103-111.

Hauser, P., Soler, R., Brucker-Davis, F, \& Weintraub, B.D. (1997). Thyroid hormones correlate with symptoms of hyperactivity but not inattention in ADHD. Psychoneuroendocrinology, 22, 107-114.

Heimann, S.W. (1999). Pycnogenol for ADHD? J. Amer. Acad. Child \& Adolesc. Psychiatry, 38, 357-358.

Hibbeln, J.R., Linnoila, M., Umhau, J.C, Rawlings, R., George, D.T., \& Salem, N. Jr (1998). Essential fatty acids predict metabolites of serotonin and dopamine in cerebrospinal fluid among healthy control subjects, and earlyand late-onset alcoholics. Biological Psychiatry (in press).

Houben, G.F., \& Penninks, A.H. (1994). Immunotoxicity of the colour additive caramel colour III: A review on complicated issues in the safety evaluation of a food additive. Toxicology, 91, 289-302.

Interactive Metronome. (1998). http://www.interactivemetronome. com/adhd.htm

Irving, W.C III (1987). A comparison of biofeedback-assisted relaxation and psychostimulants in treating children with attention deficit disorder with hyperactivity. Dissertation Abstracts International, 48-04, Section A, 0876 .

Izenwasser, S.E., Garcia-Valdez, K., \& Kantak, K.M. (1986). Stimulant-like effects of magnesium on aggression in mice. Pharmacology, Biochemistry, and Behavior, 25, 1195-1199.

Kahn, C.A, Kelly, P.C., \& Walker, W.O. Jr (1995). Lead screening in children with ADHD and developmental delay. Clinical Pediatrics, 34, 498-501.

Kaplan, B.J., McNicol, J., Conte, R.A., \& Moghadam, H.K. (1989a). Dietary replacement in preschool-aged hyperactive boys. Pediatrics, 83, 7-17.

Kaplan, B.J., McNicol, J., Conte, R.A., \& Moghadam, H.K. (1989b). Overall nutrient intake of preschool hyperactive and normal boys. J. Abnormal Child Psychology, 17, 127.

Kavale, K.A., \& Forness, S.R. (1983). Hyperactivity and diet treatment: A meta-analysis of the Feingold hypothesis. J. Learning Disabilities, 16, 324-330.

Kershner, J., \& Hawke, W. (1979). Megavitamins and learning disorders: A controlled double-blind experiment. Journal of Nutrition, 159, 819-826.

Kozielec, T., \& Starobrat-Hermelin, B. (1997). Assessment of magnesium levels in children with ADHD. Magnesium Research, 10, 143-148.

Kozielec, T., Starobrat-Hermelin, B., \& Kotkowiak, L. (1994). Deficiency of certain trace elements in children with hyperactivity. Psychiatria Polska, 28, 345-53.

Kratter, J. (1983). The use of meditation in the treatment of attention deficit disorder with hyperactivity. Dissertation Abstracts International, 44, 1965.

Krieger, G.D.R. (1985). Reduction of hyperactivity using progressive muscle relaxation imagery and autogenic exercises with electromyographic biofeedback. Dissertation Abstracts International, 46-10, Section B, 3617.

Kruesi, M.J., Rapoport, J.L., Berg, C, Stables, G., \& Bou, E. (1987). Seven-day carbohydrate and other nutrient intakes of preschool boys alleged to be behavior-responsive to sugar and their peers. In W.B. Essman (Ed.), Nutrients and brain function. Basel: Karger.

Krummel, D.A., Seligson, F.H., \& Guthrie, H.A. (1996). Hyperactivity: Is candy causal? Critical Reviews in Food Science and Nutrition, 36, 31-47.

Lee, S.W. (1991). Biofeedback as a treatment for childhood hyperactivity: A critical review of the literature. Psychological Reports 1991, 163-192.

Lester, M.L, Thatcher, R.W., \& Monroe-Lord, L. (1982). Refined carbohydrate intake, hair cadmium levels, and cognitive functioning in children. Nutrition and Behavior, 1, 3-13.

Linden, M., Habib, T, \& Radojevic, V. (1996). A controlled study of the effects of EEG biofeedback on cognition and behavior of children with attention deficit disorder and learning disabilities. Biofeedback and Self-Regulation, 21, 35-49.

Lipton, M.A., \& Mayo, J.P. (1983). Diet and hyper-kinesis—an update. J. Amer. Dietetic Assoc, 83, 132-134.

Loo, M. (1998). Laser acupuncture treatment of ADHD. Preliminary personal communication re: NIMH grant. (phone 408-356-5977).

Lubar, J.F. (1991). Discourse on the development of EEG diagnostics and biofeedback for attention-deficit/hyperactivity disorders. Biofeedback and Self-Regulation, 16, 201-225.

Lubar, J.F., \& Shouse, M.N. (1977) Use of biofeedback in the treatment of seizure disorders and 
hyperactivity. In: B.B. Lahey \& A.E. Kazdin (Eds.), Advances in clinical child psychology (Vol. 1, pp. 203-265). New York: Plenum Press.

Lubar, J.F., Swartwood, M.O., Swartwood, J.N., \& O'Donnell, P.H. (1995). Evaluation of the effectiveness of EEG neurofeedback training for ADHD in a clinical setting as measured by changes in TOVA scores, behavior ratings, and WISC-R performance. Biofeedback and Self-Regulation, 20, 83-99.

Mann, C.A., et al. (1992). Quantitative analysis of EEG in boys with attention-deficit-hyperactivity disorder: Controlled study with clinical implications. Pediatric Neurology, 8, 30-36.

Mattes, J.A. (1983). The Feingold diet: A current reappraisal. J. Learning Disabilities, 16, 319-323.

McGee, R., Williams, S., Anderson, J., McKenzie-Parnell, J.M., \& Silva, P.A. (1990). Hyperactivity and serum and hair zinc levels in 11-year-old children from the general population. Biol. Psychiatry, 28, 165-168.

Mitchell, E.A., Aman, M.G., Turbott, S.H., \& Manku, M. (1987). Clinical characteristics and serum essential fatty acid levels in hyperactive children. Clinical Pediatrics, 26, 406-411.

Mitchell, E.A., Lewis, S., \& Cutler, D.R. (1983). Essential fatty acids and maladjusted behavior in children. Prostaglandins, Leukotrienes \& Medicine, 12, 281-287.

Moretti-Altuna, G. (1987). The effects of meditation versus medication in the treatment of Attention Deficit Disorder with Hyperactivity. Dissertation Abstracts International, 47, 4658.

Mulligan, S. (1996). An analysis of score patterns of children with attention disorders on the sensory integration and praxis tests. Amer. J. Occupational Therapy, 50, 647-654.

National Institute of Health. (1982). NIH consensus development conference: Defined diets and childhood hyperactivity. Clinical Pediatrics, 21, 627-630.

Needleman, H.L., Gunnoe, C, Leviton, A., Reed, R., Peresie, H., Maher, C, \& Barrett, P. (1979). Deficits in psychologic and classroom performance of children with elevated dentine lead levels. New England Journal of Medicine. 300, 689-695.

Nemzer, E., Arnold, L.E., Votolato, N.A., McConnell, H. (1986). Amino acid supplementation as therapy for Attention Deficit Disorder (ADD). Journal of the American Academy of Child Psychiatry, 25(4), 509-513.

Neuringer, M. (1998). Overview of omega-3 fatty acids in infant development: Visual, cognitive, and behavioral outcomes. Presented at Sept. 2-3, 1998 NIH Workshop on Omega-3 Essential Fatty Acids and Psychiatric Disorders, Bethesda, MD.

Nsouli, T.M., Nsouli, S.M., Linde, R.E., O'Mara, R, Scanlon, R.T., \& Bellanti, J.A. (1994). Role of food allergy in serous otitis media. Annals of Allergy, 73, 215-219.

Omizo, M.M., \& Michael, W.B. (1982). Biofeedback-induced relaxation training and impulsivity, attention to task, and locus of control among hyperactive boys. J. Learning Disabilities, 15, 414-416.

Pakes, G.E. (1978). Death and liquid protein. American Pharmacy, 18, 4-5.

Palacios, H.J. (1976). Hypersensitivity as a cause of der-matologic and vaginal moniliasis resistant to topical therapy. Annals of Allergy, 37, 110-113.

Palacios, H.J. (1977). Desensitization for monilial hypersensitivity. Virginia Medical Journal, 393-395.

Pollock, I., \& Warner, J.O. (1990). Effect of artificial food colors on childhood behavior. Archives of Disease in Childhood, 65, 74-77.

Previc, EH. (1993). Do the organs of the labyrinth differentially influence the sympathetic and

parasympathetic systems? Neuroscience and Biobehavioral Reviews, 17, 397-404.

Prinz, R.J., Roberts, W.A., \& Hantman, E. (1980). Dietary correlates of hyperactive behavior in children. J. Consulting and Clinical Psychology, 6, 760-769.

Reimherr, F.W., Wender, P.H., Wood, D.R., \& Ward, M. (1987). An open trial of l-tyrosine in the treatment of attention deficit disorder, residual type. Amer. J. Psychiatry, 144, 1071-1073.

Rimland, B. (1983). The Feingold diet: An assessment of the reviews by Mattes, by Kavale \& Forness, and others. J. Learning Disabilities, 16, 45-49.

Rippere, V. (1983). Food additives and hyperactive children: A critique of Conners.

Rovet, J., \& Alvarez, M. (1996). Thyroid hormone and attention in school-age children with congenital hypothyroidism. Child Psychology \& Psychiatry, 37, 579-585.

Rowe, K.S. (1988). Synthetic food colorings and hyperactivity: A double-blind crossover study. Australian Pediatric Journal, 24, 143-147.

Rowe, K.S., Rowe, K.J. (1994). Synthetic food coloring and behavior: A dose-response effect in a double-blind, placebo-controlled, repeated-measures study. J. Pediatr, 125, 691-698.

Sandstead, H.H., Fosmire, G.J., Halas, E.S., Jacob, R.A., Strobel, D.A., \& Marks, E.O. (1977). Zinc 
deficiency: Effects on brain and behavior of rats and rhesus monkeys. Teratology, 16, 229-234. 239-241.

Sandyk, R. (1990). Zinc deficiency in attention-deficit/ hyperactivity disorder. Intern. J. Neuroscience, 52,

Sato, K., Taguchi, H., Maeda, T., \& Yoshikawa, K. (1993). Pyridoxine toxicity to cultured fibroblasts cause by near-ultraviolet light. /. Investigative Dermatology, 100, 266-270.

Schaumburg, H., Kaplan, J., Windebank, A., Vick, N., Rasmus, S., Pleasure, D., \& Brown, M.J. (1983).

Sensory neuropathy from pyridoxine abuse: A new megavitamin syndrome. New England Journal of Medicine, 309, 445-448.

Schmidt, M.H., Mocks, P., Lay, B., Eisert, H.G., Fojkar, R., Fritz-Sigmund, D., Marcus, A., \& Musaeus, B. (1997). Does oligoantigenic diet influence hyperactive/conduct-disordered children-A controlled trial. European Child \& Adolescent Psychiatry, 6, 88-95.

Sever, Y., Ashkenazi A., Tyano, S., \& Weizman, A. (1997). Iron treatment in children with ADHD: A preliminary report. Neuropsychobiology, 35, 178-180.

Shaywitz, B.A., Siegel, N.J., \& Pearson, H.A. (1977). Megavitamins for minimal brain dysfunction: A potentially dangerous therapy. Journal of the American Medical Association, 238, 1749-1750.

Shen, Y.C., \& Wang, Y.F. (1984). Urinary 3-methoxy-4-hydroxyphenylglycol sulfate excretion in seventy-three schoolchildren with minimal brain dysfunction. Biological Psychiatry, 19, 861-870.

Shouse, M.N., \& Lubar, J.F. (1978). Physiological basis of hyperkinesis treated with methylphenidate. Pediatrics, 62, 343-351.

Sidransky, H. (1997). Tryptophan and carcinogenesis: Review and update on how tryptophan may act. Nutrition \& Cancer, 29, 181-194.

Silbergeld, E.K., \& Goldberg, A.M. (1975). Pharmacological and neurochemical investigations of lead-induced hyperactivity. Neuropharmacology, 14, 431-444.

Simpson, D.D., \& Nelson, A.L. (1974). Attention training through breathing control to modify hyperactivity. J. Learning Disabilities, 7, 15-23.

Snodgrass, S.R. (1992). Vitamin neurotoxicity. Molecular Neurobiology, 6, 41-73.

Starobrat-Hermelin, B., \& Kozielec, T. (1997). The effects of magnesium physiological supplementation on hyperactivity in children with ADHD: Positive response to magnesium oral loading test. Magnesium Research, 10, 149-156.

Stein, T.P., \& Sammaritano, A.M. (1984). Nitrogen metabolism in normal and hyperkinetic boys. Amer.J. Clin. Nutrition, 39, 520-524.

Sternberg, E.M. (1996). Pathogenesis of L-tryptophan eosinophilia-myalgia syndrome. Advances in Experimental Medicine \& Biology, 398, 325-330.

Stevens, L.J., Zentall, S.S., Deck, J.L., Abate, M.L., Watkins, B.A., Lipp, S.R., \& Burgess, J.R. (1995). Essential fatty acid metabolism in boys with attention-deficit hyperactivity disorder. Amer. J. Clinical Nutrition, 62, 761-768.

Stillman, M. (1998). Personal communication about preliminary data from Ball State.

Swanson, J.M., \& Kinsbourne, M. (1981). Food dyes and impairment of performance in hyperactive children. Science, 211, 410-411.

Swedo, S.E., Leonard, H.L., Garvey, M., Mittleman, B., Allen, A.J., Perlmutter, S., Dow, S., Zamkoff, J., Dubbert, B.K., \& Lougee, L. (1998). Pediatric autoimmune neuropsychiatric disorders associated with streptococcal infections: Clinical description of the first 50 cases. Am. J. Psychiatry, 155, 264-271.

Sun, Y., Wang, Y., Qu, X., Wang, J, Fang, J., \& Zhang, L. (1994). Clinical observations and treatment of hyperkinesia in children by traditional Chinese medicine. J. Traditional Chinese Medicine, 14, 105-109.

Toren, P., Sofia, E., Sela, B.A., Wolmer, L., Weitz, JR., Dov, I., Koren, S., Reiss, A, Weizman, R., \& Laor, N. (1996). Zinc deficiency in ADHD. Biol. Psychiatry, 40, 1308-1310.

Truss, CO. (1991). A controlled trial of nystatin for the candidiasis hypersensitivity syndrome. (Letter to editor). New England Journal of Medicine.

Valentine, J., Rossi, E., O'Leary, P., Parry, T.S., Kurinczuk, J.J., \& Sly, P. (1997). Thyroid function in a population of children with ADHD. J. Pediatrics \& Child Health, 33, 117-120.

Vargas, S.L., Patrick, C.C., Ayers, G.D., \& Hughes, W.T. (1993). Modulating effect of dietary carbohydrate supplementation on Candida albicans colonization and invasion in a neutropenic mouse model. Infection and Immunity, 61, 619-626.

Voight, R.G., Llorente, A., Jensen, C.L., Berretta, M.C., Boutte, C, \& Heird, W.C. (1998). Effect of dietary 
docosohexaenoic acid supplementation on children with ADHD: Preliminary unpublished data presented at NIH workshop on Omega-3 Essential Fatty Acids and Psychiatric Disorders, Sept. 2-3, 1998, Bethesda, MD.

Wagner, K.R, Elmore, J.G., \& Horwitz, R.I. (1996). Diagnostic bias in clinical decision making: An example of L-tryptophan and the diagnosis of eosinophilia-myalgia syndrome. J. Rheumatology, 23, 2079-2085.

Wang, L.H., Li, C.S., \& Li, G.Z. (1995). Clinical and experimental studies on tiaoshen liquor for infantile hyperkinetic syndrome. Chung-Kuo Chung Hsi i Chieh Ho Tsa Chih, 15, 337-340.

Weiss, R.E., \& Stein, M.A. (1998, in press). Thyroid function and attention deficit hyperactivity disorder. In

P. Accardo, T. Blondis, B. Whitman, \& M. Stein (Eds.), ADHD in children and adults. New York: Marcel Dekker.

Weiss, R.E., Stein, M.A., \& Refetoff, S. (1997). Behavioral effects of liothyronine (L-T3) in children with

ADHD in the presence and absence of resistance to thyroid hormone. Thyroid, 7, 389-393.

Weiss, R.E., Stein, M.A., Trommer, B., \& Refetoff, S. (1993). Attention-deficit hyperactivity disorder and

thyroid function. Pediatrics, 123, 539-545.

West, S.A, Sax, K.W., Stanton, S.P, Keck, PE. Jr, McElroy, S.L., \& Strakowski, S.M. (1996). Differences in thyroid function studies in acutely manic adolescents with and without ADHD. Psychopharmacology Bulletin, 32, 63-66.

Williams, J.I., \& Cram, M.C. (1978). Diet in the management of hyperkinesis. Canadian Psychiatric Association Journal, 23, 241-248.

Williamson, B.L., Tomlinson, A.J., Mishra, P.K., Gleich, G.J., \& Naylor, S. (1998). Structural

characterization of contaminants found in commercial preparations of melatonin: Similarities to case-related compounds from L-tryptophan associated with eosinophilia-myalgia syndrome. Chemical Research in Toxicology, 11, 234-240.

Wolraich, M.L., Lindgren, S.D., Stumbo, P.J., Stegink, L.D., Appelbaum, M.I., \& Kiritsy, M.C. (1994).

Effects of diets high in sucrose or aspartame on the behavior and cognitive performance of children. N. Engl. J. Med., 330, 301-307.

Wolraich, M.L., Stumbo, P.J., Milch, R., Chenard, C, \& Schultz, F. (1986). Dietary characteristics of hyperactive and control boys. /. Am. Diet. Assoc, 86, 500.

Wolraich, M.L., Wilson, D.B., \& White, J.W. (1995). The effect of sugar on behavior or cognition in children. Journal of the American Medical Association, 274, 1617-1621.

Wood, D.R., Reimherr, F.W., \& Wender, PH. (1985a). Treatment of attention-deficit disorder with dl-phenylalanine. Psychiatry Research, 16, 21-26.

Wood, D.R., Reimherr, F.W., \& Wender, PH. (1985b). Amino acid precursors for the treatment of attention-deficit disorder, residual type. Psychopharmacology Bulletin, 21, 146-149.

Yates, B.J. (1992). Vestibular influences on the sympathetic nervous system. Brain Research Reviews, 17, 51-59.

Zametkin, A.J., Karoum, E, \& Rapoport, J. (1987). Treatment of hyperactive children with d-phenylalanine. Amer. J. Psychiatry, 144, 792-794.

Zentall, S.S., Hall, A.M., \& Lee, D.L. (1998). Attentional focus of students with hyperactivity during a word-search task. Abnormal Child Psychology, 26, 335-343.

Zhang, H., \& Huang, J. (1990). Preliminary study of traditional Chinese medicine treatment of minimal brain dysfunction: Analysis of 100 cases. Chung Hsi i Chieh Ho Tsa Chih [Chinese Journal of Modern Developments in Traditional Medicine], 10, 278-279. 